\title{
An overview of nickel mineralisation in Africa with emphasis on the Mesoproterozoic East African Nickel Belt (EANB)
}

\author{
D. M. Evans ${ }^{1}$, J. P. P. M. Hunt ${ }^{2}$, and J. R. Simmonds ${ }^{3}$ \\ ${ }^{1}$ Carrog Consulting, 21 rue Jean de la Bruyère, 78000 Versailles, France. E-mail: evans_dave_m@hotmail.com \\ ${ }^{2}$ Council for Geoscience, Private Bag X112, Pretoria 0001, South Africa \\ ${ }^{3}$ Nyiici Pty Ltd, 64 McKenzie Street, Wembley WA 6014, Australia
}

DOI: 10.18814/epiiugs/2016/v39i2/95780

Nickel production in Africa takes place principally in Botswana, South Africa and Zimbabwe, with much of the South African and Zimbabwean production being a by-product of platinum-group element mining in the Bushveld Complex and Great Dyke. Several large nickel deposits have been discovered elsewhere in Africa but until recently, their development has been hindered by political risk and limitations in energy and transport infrastructure. Most of the continent is significantly underexplored with respect to base metals, including the area covered by the East African Nickel Belt (EANB).

The known nickel deposits of the EANB all occur in mafic-ultramafic intrusive rocks of the Mesoproterozoicage Kibaran igneous event. These intrusive bodies take the form of medium to large layered intrusions, small dynamic magma conduits (chonoliths and sills) and dyke swarms. Laterite deposits are developed over exposed dunite and peridotite lithologies in the basal sequence of larger layered intrusions, whereas nickel sulphide deposits are developed at the base of the small chonoliths. Geochronological and geochemical data suggests that all intrusions in the EANB formed in a single magmatic event ( 1350 to $1400 \mathrm{Ma}$ ) and were derived from a picritic parental magma, which was variably contaminated in mid to upper-crustal staging chambers by metasedimentary rocks. As a result, nickel sulphide mineralisation was formed in all of the intrusions, but in most, the grades and tenors are too low to be considered economic in the foreseeable future.

In the 1970s, government-led regional surveys identified a large nickel laterite deposit at Musongati in Burundi and a nickel sulphide deposit at Kabanga in the northwest of Tanzania. These deposits have subsequently been explored and delineated by mining companies, but they remain undeveloped due to their distance to the coast and a lack of transport and energy infrastructure. The Kabanga sulphide deposit now comprises a total mineral resource of 58 million tonnes grading $2.6 \%$ nickel. The Musongati laterite deposit comprises an overall resource of 122 million tonnes with a grade of $1.4 \%$ nickel.

\section{Introduction and geological setting of nickel deposits}

The vast majority of nickel deposits worldwide are hosted by or related to rocks of mafic to ultramafic composition, either as products of crystallization from primitive mantle melts (picritic and tholeiitic basalt or komatiitic magma) or, tectonically-emplaced slices of upper mantle (ophiolites and alpine-type ultramafic bodies). Certain time periods such as the late Archaean and late Palaeoproterozoic appear to have been more conducive to the formation of significant deposits than others (Naldrett, 2010). Two main types of nickel deposit are currently exploited: sulphide (in which nickel is associated with copper and platinum-group elements) and laterite (in which nickel is associated with cobalt). A third type, metal-rich nodules on the deep sea floor, is poorly quantified and uneconomic to exploit at the present time (Mudd, 2010). Examples of significant sulphide and laterite deposit types occur throughout Africa (Mudd and Jowitt, 2014). This paper reviews the status of nickel exploration and production in Africa, before focusing on the Mesoproterozoic-aged (Kibaran) East African Nickel Belt (EANB), sometimes also known as the Central African Nickel Belt.

\section{An Overview of Nickel in Africa}

\section{History of exploration in Africa}

Gold, copper and iron have been searched for and exploited in Africa for centuries. Nickel (Ni), however, was not known or exploited in Africa before the advent of colonialism except fortuitously, due to its association with iron or copper. For example, the gossans over the Selkirk and Phoenix nickel deposits of northern Botswana were exploited for their copper and iron by pre-colonial metal-workers (Johnson, 1986). 
Prior to the Second World War, exploitation of nickel was restricted to small high-grade deposits such as at Bon Accord (Mpumalanga, South Africa: De Waal, 1986), or as a by-product of other metals, for example, copper $(\mathrm{Cu})$ at Waterfall Gorge (Eastern Cape, South Africa: Maske and Cawthorn, 1986) or cobalt (Co) at Bou-Azzer (Morocco: Gandini, 2011). The 1920s also saw the beginnings of production of nickel as a by-product of mining and refining of platinum-group elements (PGE) from the Bushveld Complex (Wagner, 1929).

The Second World War and its aftermath greatly enhanced the demand for nickel as a highly strategic metal, used both in armaments (tanks, guns, warships) and increasingly in everyday life (stainless steel and coinage). The post-war demand and an upsurge in exploration in the 1950s, led to discoveries of $\mathrm{Ni}-\mathrm{Cu}$ sulphide deposits in Zimbabwe: Empress in 1956 (Anderson, 1986), Trojan in 1959 (Chimimba and Ncube, 1986), Madziwa in 1959 (Chimimba 1986) and in Botswana - Selebi in 1963 and Phikwe in 1966 (Gordon, 1973). The worldwide nickel boom of the 1960s and a technological and fiscal spur by the sanctions-hit Rhodesian government, led to further discoveries (Epoch and Shangani) and development of mining, smelting and refining centres in Botswana and Zimbabwe in the late 1960s and early 1970s (Mikesell, 1984; Marchand, 1996).

Until the early 1970s, African nickel exploration outside of southern Africa was quite limited. One can cite the systematic investigation of known mafic-ultramafic intrusive bodies throughout Africa by the International Nickel Company (INCO), from 1950 to 1959 , that resulted in the discovery and drilling of surface $\mathrm{Cu}-\mathrm{Ni}$ showings at the Kapalagulu Complex and at Ntaka Hill, both in Tanzania (Van Zyl, 1959; Tirschmann et al., 2010). In the early 1960s, the large Ni laterite deposit at Ambatovy (Madagascar: Ambatovy JV, 2014) was discovered and further deposits of Co-Ni-arsenides were found in Morocco as a result of systematic exploration (Gandini, 2011).

Subsequent to the independence of many African countries, mineral exploration was accelerated throughout the 1970s and 1980s, particularly with the direct aid of multilateral organisations (e.g. United Nations Development Program/Programme des Nations Unies pour le Développement - UNDP/PNUD). This led to the discovery of large nickel deposits in African countries that had not previously been prospected for base metals. Among the major discoveries of the 1970s were those of the Sipilou-Foungbesso (Biankouma) Ni-Co laterite deposits in western Côte d'Ivoire, the Nkamouna Ni-Co-manganese $\mathrm{Mn}$ ) laterite in Cameroon, the Musongati $\mathrm{Ni}-\mathrm{Cu}-\mathrm{Co}$ laterite deposits of Burundi, and the Kabanga Ni sulphide deposit of northwest Tanzania (the latter two in the EANB).

\section{Production and new developments}

Currently, African nickel is produced mainly in Botswana, South Africa and Zimbabwe (Table 1). All of the primary Ni producers are of low to very low average $\mathrm{Ni}$ grade $(<1.5 \%)$ and thus their operations are adversely affected when Ni prices are low (Mikesell, 1984).

In southern Africa, the largest estimated resources of nickel are in the sulphide-bearing platinum reefs of the Bushveld Complex, from which nickel is produced as a by-product of PGE mining (estimated 7 to 10 Mt contained nickel metal) (Cawthorn, 1999). However, the largest individual resource of nickel as a primary product is that of the Nkomati deposit in South Africa (0.82 Mt contained Ni at $0.34 \%$ $\mathrm{Ni}$, African Rainbow Minerals, 2014). Approximately 1 Mt of nickel
Table 1. Major centres of nickel production in Southern Africa

\begin{tabular}{|c|c|c|c|c|c|}
\hline Country & $\begin{array}{l}\text { Mine/ } \\
\text { Site }\end{array}$ & $\begin{array}{l}\text { Ore } \\
(\mathrm{Mt})\end{array}$ & $\begin{array}{c}\text { Contained } \\
\mathrm{Ni}(\mathrm{t})\end{array}$ & $\begin{array}{c}\text { Head } \\
\text { grade } \mathrm{Ni}\end{array}$ & Year \\
\hline Botswana & $\begin{array}{l}\text { Tati Ni } \\
\text { Selebi-Pikwe }\end{array}$ & $\begin{array}{c}11.67 * * \\
2.81 *\end{array}$ & $\begin{array}{c}8,100 \\
17,800\end{array}$ & $\begin{array}{l}0.15 \% \\
0.63 \%\end{array}$ & $\begin{array}{l}2013^{1} \\
2010^{2}\end{array}$ \\
\hline S. Africa & $\begin{array}{l}\text { Nkomati Ni } \\
\text { Bushveld Pt }\end{array}$ & $\begin{array}{l}7.93 * \\
29.3 *\end{array}$ & $\begin{array}{l}22,874 \\
29,954\end{array}$ & $\begin{array}{l}0.39 \% \\
0.10 \%\end{array}$ & $\begin{array}{l}2014^{3} \\
2014^{4}\end{array}$ \\
\hline Zimbabwe & $\begin{array}{l}\text { Bindura Ni } \\
\text { Gt. Dyke Pt }\end{array}$ & $\begin{array}{c}0.59 * \\
10.65 *\end{array}$ & $\begin{array}{l}7,026 \\
9,859\end{array}$ & $\begin{array}{l}1.38 \% \\
0.09 \%\end{array}$ & $\begin{array}{l}2014^{5} \\
2014^{4}\end{array}$ \\
\hline
\end{tabular}

1 - Norilsk-Nickel 2013; 2 - Bamangwato Concessions Ltd. 2014; 3 African Rainbow Minerals 2014; 4 - Anglo-American Platinum 2014 and Impala Platinum 2014; 5 - Mwana Africa 2014. * - milled ore; ** - mined ore.

is contained in the combined resources of the Phoenix-Tati and SelebiPikwe deposits in Botswana (Bamangwato Concessions Ltd., 2014). Most of the Zimbabwean primary nickel mines have been depleted or temporarily closed due to political and economic factors, but they still contain at least $0.4 \mathrm{Mt}$ of $\mathrm{Ni}$ as defined mineral resources (Mwana Africa, 2014). In northwestern Zambia, a new type of hydrothermal Ni sulphide deposit (Enterprise) is being developed, which contains approximately $0.5 \mathrm{Mt}$ of $\mathrm{Ni}$ with an average grade of about $1 \%$ (First Quantum, 2014).

The major African Ni laterite deposits discovered in the 1970s have for the most part remained undeveloped, principally due to their distance from suitable deep-water ports, and the lack of infrastructure (power and transport links) within their host countries. Only the laterite deposit at Ambatovy in Madagascar, has been developed and was brought into production in 2012 by a multinational consortium (Ambatovy J.V., 2014).

\section{The East African Nickel Belt (EANB)}

\section{Location and infrastructure}

The major component of the EANB is located in Burundi and western Tanzania (Fig. 1A), with poorly documented probable extensions into adjacent areas of eastern Rwanda, southern Uganda and east-central Democratic Republic of Congo (DRC). Most of the outcrop is located in a rugged uplifted plateau area adjacent to the western branch of the East African Rift Valley, where the natural vegetation is grassland savannah with riverine forests and sparse woodlands. Critically, the region is landlocked, with poor transport links to the Indian Ocean coast via a narrow-gauge railway in central Tanzania, a standard-gauge railway through Uganda and Kenya or by 2-lane paved and unpaved roads (Anonymous, 2012). Power in the region is mainly generated by small to medium sized hydroelectric schemes (e.g. on the Ruzizi river in Rwanda and DRC), or by small scale and costly diesel generation (Nile Basin Initiative, 2014).

\section{Background and early history of the EANB}

The Kapalagulu layered intrusion in western Tanzania was identified before the First World War by German geologists who noted its potential for nickel-copper sulphide mineralisation on the basis of its similarity to the Sudbury intrusion (Teale, 1932). Further reconnaissance mapping at Kapalugulu was undertaken by the British administration in the 1930 s, but it was not until the 1950 s that 


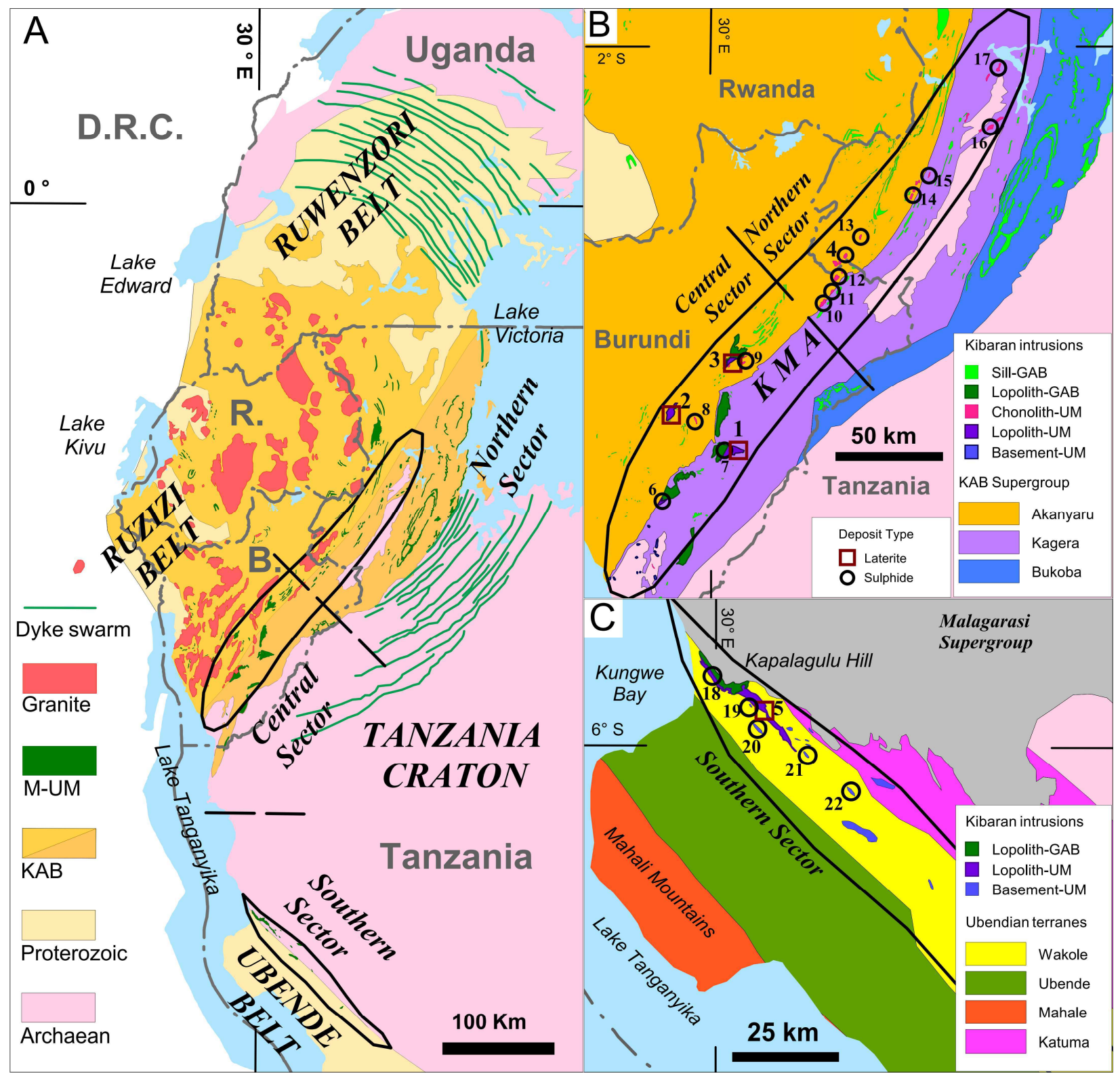

Figure 1. (A) Location of the East Africa Nickel Belt, showing the extent of the Karagwe-Ankole Belt metasedimentary rocks (KAB), Kibaran granites (Granite) and mafic-ultramafic intrusions (M-UM). Country abbreviations: B. - Burundi; D.R.C. - Democratic Republic of Congo; $R$. - Rwanda. (B) Location map of Ni deposits and prospects in the Kabanga-Musongati Alignment (KMA) (numbered as in Table 3). Area underlain by Archaean crust is in pale pink, and by Paleoproterozoic crust is in pale orange. Intrusion type abbreviations: GAB gabbroic; UM - ultramafic. (C) Location of the Kapalagulu intrusion in the Wakole terrane of the Ubendian Belt. Maps after Evans et al. (2000), Tack et al. (2010), Fernandez-Alonso et al. (2012), Boniface et al. (2014), Mäkitie et al. (2014).

commercially-focused exploration began, resulting in the 1951 discovery by the Canadian company INCO, of nickeliferous sulphides in a basal "picrite" or olivine-rich norite (Van Zyl, 1959). Further investigations at Kapalagulu and other parts of the Palaeoproterozoicage Ubendian Belt, were carried out by Anglo-American Corporation and other organizations through the 1950s to early 1970s, resulting in the discovery of lateritic $\mathrm{Ni}$ and $\mathrm{Cr}$ mineralisation at Kapalagulu (Bursill, 1959).

Burundi, Rwanda, the adjacent areas of northwestern Tanzania and southern Uganda, were first geologically mapped on a broad scale in the 1930s and the terms Burundian and Karagwe-Ankole series were introduced for the folded metasedimentary rocks that dominate this area (Combe, 1932; Salée, 1932). Outcrops and scattered boulders of doleritic and gabbroic rocks associated with granite batholiths were noted within the metasediments of the Karagwe-Ankole belt. More systematic geological mapping of the region commenced in the 1960s (Waleffe, 1966; Grey, 1967), resulting in the recognition of a large Mesoproterozoic bimodal igneous province (Cahen et al., 1984). During this mapping, a small occurrence of garnierite (bright green Ni silicate) was found near Nyabikere in Burundi (Deblond, 1992).

This garnierite occurrence, combined with the mapping of large gabbroic bodies in central and southern Burundi, led to the initial UNDP-assisted exploration program, which resulted in the discoveries of Ni-laterite mineralisation at Musongati and Nyabikere in 1972 and at Waga in 1973 (Programme des Nations Unies pour le Développement, 1977). A similar UNDP-aided exploration 
Table 2. Published mineral resources for some nickel deposits of the East African Nickel Belt.

\begin{tabular}{|c|c|c|c|c|c|c|c|}
\hline \multirow{2}{*}{ Deposit } & \multirow{2}{*}{$\begin{array}{l}\text { Ore } \\
\mathrm{Mt}\end{array}$} & \multicolumn{2}{|c|}{ Grade } & \multirow{2}{*}{$\begin{array}{l}\text { Contained } \\
\text { Ni kt }\end{array}$} & \multirow{2}{*}{$\frac{\text { Cutoff }}{\mathrm{Ni} \%}$} & \multirow{2}{*}{ Year } & \multirow{2}{*}{ Category } \\
\hline & & $\mathrm{Ni} \%$ & Co $\%$ & & & & \\
\hline Musongati & $122.5^{6}$ & 1.43 & & 1,746 & 0.8 & $1985^{1,2}$ & U*Ind\&Inf \\
\hline Nyabikere & 46 & 1.45 & & 667 & 0.8 & $1975^{3}$ & $\mathrm{U}^{*}$ \\
\hline Waga & 38 & 1.38 & & 483 & 0.8 & $1975^{3}$ & $\mathrm{U}^{*}$ \\
\hline Kapalagulu & 55.1 & 0.96 & 0.05 & 529 & 0.8 & $2005^{4}$ & $\mathrm{~J}^{*} \operatorname{Inf}$ \\
\hline Kabanga & 58.2 & 2.62 & 0.2 & 1,526 & $1.0^{7}$ & $2013^{5}$ & N*M\&I\&I \\
\hline
\end{tabular}

1 Buminco (1990); 2 Programme des Nations Unies pour le Développement (1979); 3 Programme des Nations Unies pour le Développement (1977); 4 Goldstream Mining (2005); 5 Glencore (2014); 6 Includes a high-grade portion of $29.1 \mathrm{Mt}$ grading $1.62 \% \mathrm{Ni} ; \mathrm{Cut-off}$ uses a Ni-equivalent calculation that approximates to $1 \% \mathrm{Ni}$. Abbreviations: Cont $\mathrm{Ni}$ - contained $\mathrm{Ni}$ metal: $\mathrm{U}^{*}$ - unclassified resource: $\mathrm{J}^{*}$ JORC-compliant resource: N* - NI43-101-compliant resource : Inf - Inferred : Ind\&Inf - indicated and inferred: M\&I\&I - Measured and indicated and inferred.

programme began in the adjacent Kagera region of Tanzania, which identified laterite-covered ultramafic rocks at Kabanga in 1976. Using soil geochemistry and ground geophysics, a follow-up UNDP drilling programme confirmed the presence of massive nickel sulphides some $5 \mathrm{~km}$ to the north of the lateritized ultramafic rocks at Kabanga in 1978 (United Nations Development Program, 1980).

Subsequent commercial exploration in the belt since 1990 has followed up on the UNDP discoveries. The significant nickel laterite deposits that overlie ultramafic portions of layered intrusions at Musongati, Nyabikere and Waga in Burundi, and at Kapalagulu in Tanzania, have had their resources defined and beneficiation characteristics quantified (Table 2) (Buminco, 1990). Nickel sulphide mineralisation has been identified throughout the region, with the most significant deposit at Kabanga having been the subject of multiple scoping and feasibility studies (Barrick Gold, 2007; Lindsay, 2010).

\section{Regional geological setting}

The EANB can be divided into northern, central and southern sectors, their possible continuity being interrupted by the Cainozoic to Recent western arm of the East African Rift Valley, now occupied by Lake Tanganyika (Fig. 1A). The EANB straddles the western boundary of the Archaean Tanzania craton with the Palaeoproterozoic Ruzizi-Ruwenzori metamorphic belt in the north, and with the Ubendian metamorphic belt in the south (Fig. 1). In the northern and central sections, a thick package of Palaeo- to Mesoproterozoic metasedimentary rocks known as the Karagwe-Ankole Belt (KAB) overlies this boundary, within which occurs a suite of broadly coeval, bimodal igneous intrusions (Fig. 1). These igneous rocks belong to the Kibaran tectonothermal event and province, which is a widespread magmatic and metamorphic event that affected the Karagwe-Ankole and Kibara belts between 1350 to $1400 \mathrm{Ma}$ (Kokonyangi et al., 2006; Tack et al., 2010).

The distribution of these intrusive suites, and of the metamorphism and tectonism related to them, led Tack et al. (1994) to divide the $\mathrm{KAB}$ into a Western Domain (WD) and an Eastern Domain (ED), separated by a narrow Transitional Domain (TD). The ED is characterized by relatively lower degrees of metamorphism and tectonism, by the absence of granitic intrusions of the Kibaran event, and by the lowermost sediments lying unconformably on Archaean crust. The WD, by contrast, is characterized by higher degrees of metamorphism and of polyphase deformation, the intrusion of voluminous Kibaran granites, and by the absence of any recognizable primary sediment-basement relationship. The transitional boundary between the two domains, which coincides with the interpreted boundary between Archaean and Palaeoproterozoic lithospheric domains (Fig. 1A), is marked broadly by a NE-SW-trending line of mafic-ultramafic intrusions known as the Kabanga-Musongati Alignment (KMA: Tack et al., 1994; Deblond and Tack, 1999). It is noteworthy that Kibaran S-type granitoids occur only to the west of this trendline (Tack et al., 1994), whereas a large arcuate mafic dyke swarm (the Lake Victoria Dyke Swarm of Mäkitie et al., 2014) occurs only to the east of this trend line (Fig. 1).

The stratigraphy of the Karagwe-Ankole belt metasedimentary rocks has been recently formalized on a regional scale by FernandezAlonso et al. (2012) and we broadly follow their proposed nomenclature (Fig. 2). These authors propose a sharp geographical division into two distinct sedimentary sub-basins, containing the Akanyaru Supergroup (sedimentary rocks of the WD), and the Kagera Supergroup (sedimentary rocks of the ED). Both of these Supergroups consist of alternating arenaceous and pelitic rocks, including quartzites, schists, greywackes and conglomerates, deposited in longlived shallow-water intracratonic or pericontinental basins. Analysis of detrital zircon from the sedimentary rocks show that deposition in the Kagera Supergroup basin occurred between $1.78 \mathrm{Ga}$ and $1.37 \mathrm{Ga}$, whereas in the Akanyaru basin, deposition was confined to between $1.42 \mathrm{Ga}$ and $1.37 \mathrm{Ga}$, with no apparent correlation between them (Fernandez-Alonso et al., 2012).

The Mesoproterozoic igneous rocks comprise a mafic-ultramafic intrusive suite (dykes, sills and layered intrusions) and a coeval felsic suite (granitic intrusions). The nickel deposits are exclusively found within the mafic-ultramafic intrusions, particularly along the KabangaMusongati Alignment (KMA) (Fig. 1B) (Deblond and Tack, 1999; Evans et al., 2000). This narrow belt contains well-differentiated lopolithic layered intrusions (dunite, peridotite, pyroxenite, gabbronorite and anorthosite), as well as chonoliths (small, narrow, tube-like sills, often concentrically zoned), whereas poorlydifferentiated dykes and sills of a more evolved gabbronoritic composition occur on a regional scale outside of the KMA belt (Fig. 1A, B). The Lake Victoria Dyke Swarm (LVDS) occurs in Archaean and Palaeoproterozoic basement rocks to the east of the exposed KAB (Fig. 1A). The dykes have been dated by Mäkitie et al. (2014) to between $1368 \pm 41 \mathrm{Ma}$ and $1374 \pm 42 \mathrm{Ma}$, and Westerhof et al. (2014) group them with the Kibaran magmatism within the KAB. 


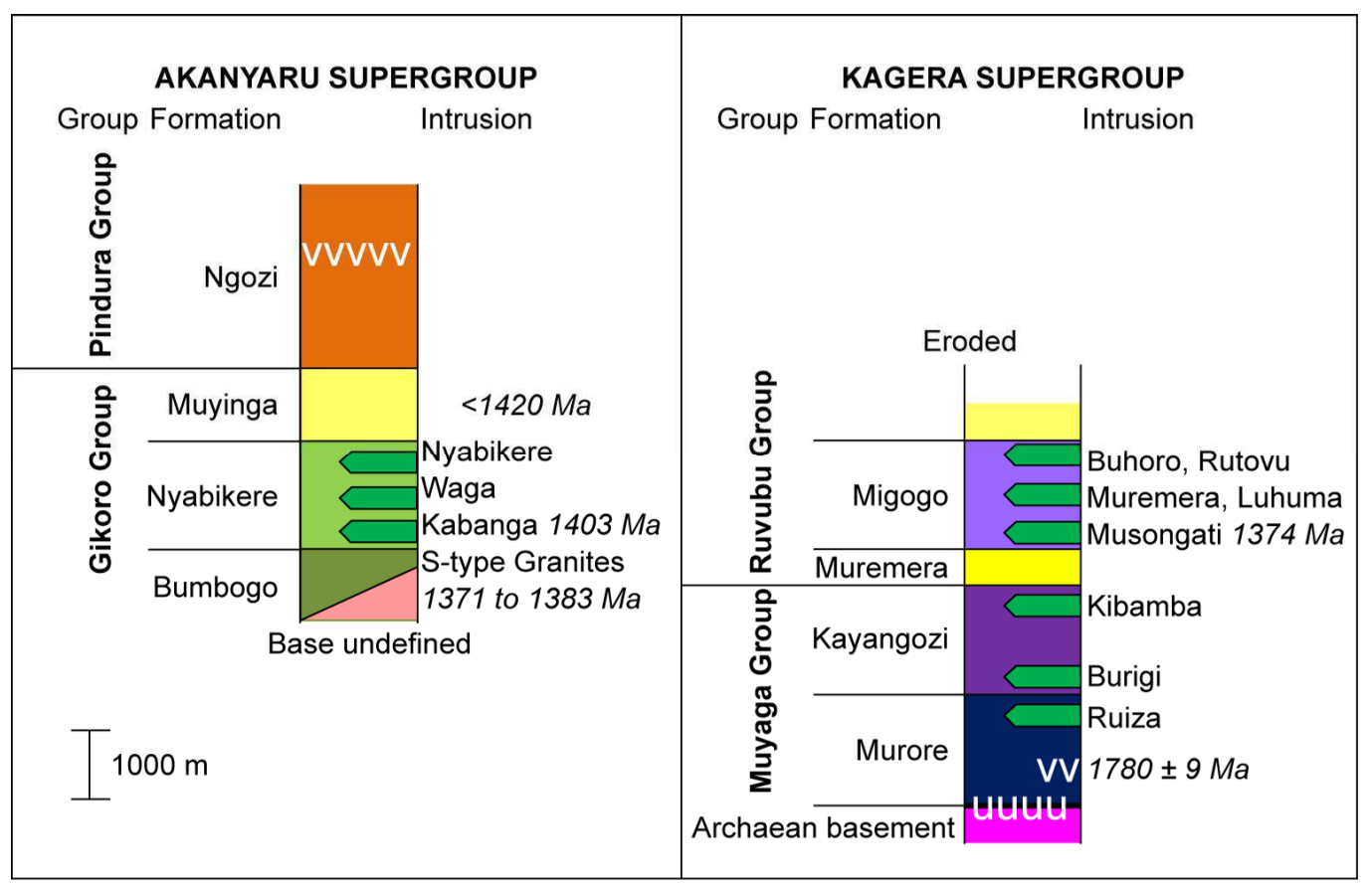

Figure 2. Synthetic stratigraphy of the Karagwe-Ankole belt after Fernandez-Alonso et al. (2012), with emplacement position and ages of various Kabanga-Musongati Alignment intrusions associated with laterite or sulphide Ni deposits. Radiometric age dates are referred to in the text. U-symbol in column - unconformity; V-symbol in column - volcanic rock. Indicated scale is very approximate. Note that we tentatively maintain the lateral correlation between Migogo Formation of the Kagera Supergroup and the Nyabikere Formation of the Akanyaru Supergroup (Waleffe, 1966).

The larger intrusions are considered to be Bushveld-type intracontinental layered igneous complexes with largely cumulate textures, displaying magmatic layering and contact metamorphic aureoles in the host rocks (Deblond, 1994; Duchesne et al., 2004). The intrusions are thought to have been derived from a magnesiumrich mantle-derived magma, emplaced between 1374 and $1403 \mathrm{Ma}$ (Maier et al., 2007; Tack et al., 2010).

Two types of parental magma influxes have been invoked by Duchesne et al., (2004) for the mafic-ultramafic intrusions: a magma, broadly picritic in composition and a more evolved basaltic magma, geochemically similar to the Bushveld Main Zone magma, both believed to come from enriched subcontinental lithospheric mantle. Maier et al. (2008, 2010), however, postulate a single picritic (ca $15 \% \mathrm{MgO}$ ) parental magma for all the mafic-ultramafic intrusions, which they believe was derived from the deeper asthenosphere and which was then variably contaminated by continental crustal material during its ascent.

\section{Classification of deposits}

The nickel deposits of the belt are of two types: lateritic and sulphidic. The lateritic deposits are developed over the olivine-rich ultramafic portions of the larger, layered intrusions (lopoliths), where a thick weathered blanket has been preserved from uplift and erosion. Weak, low grade sulphide mineralisation is ubiquitous in almost all known mafic-ultramafic intrusions of the belt. The sulphidic deposits occur as more concentrated segregations of massive or semi-massive sulphide within the smaller tube-like sills (chonoliths).

Geographically, the deposits can be divided into three groups, the northern, the central and the southern sectors (Fig. 1A, B and C). The northern and central sectors are situated within the Karagwe-
Ankole belt, whereas the southern group is situated within the Ubendian belt. The northern sector comprises largely sulphide deposits hosted in small ultramafic chonoliths, including the Muremera, Kabanga, Luhuma and Kibamba deposits or occurrences (Fig. 1B). The central sector comprises mainly the well-known Burundian nickel laterite deposits that are associated with larger layered lopolith bodies, but does include some sulphide deposits associated with smaller maficultramafic intrusions such as Ranga, Nyabiraba and Rutovu (Fig. 1B). The southern sector comprises the sulphide and laterite mineralisation of the Kapalagulu layered intrusion, plus some smaller sulphidebearing intrusions along strike to the southeast (Fig. 1C).

Five of the deposits have had sufficient exploration and evaluation work completed on them to allow the estimation of sizeable mineral resources (Table 2). These include one deposit each from the northern and southern sectors and three from the central sector. In the following section, the major deposits with estimated resources from each of the three geographic groupings will be described in more detail. These descriptions will also refer to geological and exploration work undertaken on nearby or related intrusions or anomalies during the evaluation of the major deposits.

\section{Kabanga Nickel Sulphide Deposit}

\section{Background}

Subsequent to the discovery in 1978 of massive sulphide mineralisation at Kabanga by the Tanzanian government-UNDP team, commercial exploration has been carried out almost continuously since 1991. Various foreign mining and exploration companies, including Sutton Resources Ltd., BHP Minerals International Ltd., AngloAmerican Corporation Ltd. and Barrick Gold Corporation have held 
the exploration licences through ownership of a Tanzanian-registered entity, Kabanga Nickel Company Ltd.

In 2005, Falconbridge Ltd. (now owned by Glencore Plc) entered into a joint venture with Barrick Gold Corporation to carry out scoping and feasibility studies on the Kabanga deposit. The deposit is currently held under a retention licence that was renewed in 2014 for a period of five years (Glencore, 2014).

\section{Deposit Geology}

The intrusions that contain the deposit are hosted within steeplydipping to overturned metasediments adjacent to the Bushubi foliated S-type granite (Fig. 3A). The sedimentary package is made up of about $90 \%$ metapelites and metasiltstones, and the remaining $10 \%$ of the stratigraphy comprises relatively clean arenitic metasandstones (quartzites). The metapelite rocks are graphitic in places and can contain up to 5 modal $\%$ of pyrrhotite as thin layering-parallel laminae and lenses. They are schistose to phyllitic, with the metamorphic fabric dipping steeply to the WNW. The metamorphic grade decreases in intensity from amphibolite facies adjacent to the granite, to lower greenschist facies to the east (Grey, 1967).

The deposits are contained within and at the bottom margin of at least two and perhaps three or four, mafic-ultramafic chonoliths that are emplaced into the banded semipelite and micaceous phyllite subunits. At their lateral margins, and above and below them, thinner doleritic or gabbronoritic sills extend conformably into the adjacent metasedimentary rocks. The chonoliths themselves have a gabbronoritic margin and an olivine-orthopyroxene-enriched cumulate core zone (Fig. 3A). This core zone varies in rock type from sulphidic dunite, plagioclase-peridotite, orthopyroxenite, to olivine melanorite, and shows a crude modal and grainsize layering parallel to the bedding of the enclosing metasedimentary rocks (Evans et al., 2000; Maier et al., 2010).

The marginal rocks vary from gabbronorite to melanorite, usually with a predominance of orthopyroxene over clinopyroxene. Quartz and phlogopite are common accessories, interstitial to the more idiomorphic plagioclase and pyroxene. The marginal rocks often contain partly-digested xenoliths, and show evidence of hybridization with partial melts of metasedimentary rock (Maier $e t$ $a l ., 2010)$. Zircons extracted from a marginal gabbroic rock of the Kabanga North intrusion were dated by the Sensitive High-Resolution Ion Microprobe (SHRIMP) method at $1403 \pm 14$ Ma by Maier et al. (2007).

\section{Description of mineralisation}

Sulphide mineralisation occurs both within the Kabanga chonoliths as disseminated to net-textured interstitial sulphides within the cumulate core zone, as well as externally, as massive and semimassive bodies along the lower or side margins of the chonolith (Evans et al., 1999; Maier et al., 2010). The internal disseminated sulphides partially enclose cumulate olivine and poikilitic orthopyroxene crystals, displacing the normal interstitial assemblage of plagioclase, clinopyroxene and phlogopite. This suggests that the sulphide was emplaced interstitially in the molten form at the time of accumulation of olivine and orthopyroxene. The composition of the internal sulphides varies considerably resulting in tenors of 5 to $6 \% \mathrm{Ni}$ near the basal margin, to tenors of only 0.5 to $1 \% \mathrm{Ni}$ in the upper cumulates (Evans et al., 1999; Maier and Barnes, 2010). Most of the internal sulphides, however, have grades at or below $1 \% \mathrm{Ni}$ and are not included within the mineral resources (Glencore, 2014).

The external sulphides are located at, or just within, the lower margin of the chonolith and form the bulk of the defined mineral resources (Fig. 3B). External sulphides take the form of subconformable layers or lenses of massive or semi-massive sulphide and often contain chaotic fragments of metasedimentary or gabbronoritic wallrocks, suggesting forceful and dynamic emplacement. The external sulphides vary in tenor to a similar degree as the internal sulphides. At Kabanga it is found as a general rule that the smaller intrusive bodies (in terms of cross-sectional area) that occur lower in the sedimentary stratigraphy, such as Kabanga North and Tembo, are more richly endowed with external massive sulphide mineralisation (Fig. 3B and C). The mineralisation within these smaller chonoliths is located more distally from the intrusion, has a higher proportion of massive sulphide, and the pyrrhotite/pentlandite ratio within the sulphide is lower (Maier et al., 2011).

\section{Mineral resources and exploration}

Both the tonnage and the grade estimates of the mineral resources at Kabanga have increased dramatically since the first resource estimate on the Kabanga Main body which was carried out by the UNDP in 1979 (21 Mt grading 1.0\% Ni: United Nations Development Program, 1980). The discovery by electromagnetic (EM) ground surveys of the nearby Kabanga North body in 1993 and the Tembo body in 2006 and more than 500,000 metres of drilling, have allowed a dramatic increase of the size and quality of defined mineralisation in the current mineral resource estimate (Table 2).

Exploration drilling was also carried out at the Nyabiraba, Muremera, Rujungu, Luhuma, Kibamba, Ruiza and Burigi chonolith clusters, in all of which $\mathrm{Ni}$ sulphide mineralisation was encountered (Fig. 1B; Table 3). However, no mineral resources were estimated at these prospects due to the generally low grade and low tenor of this sulphide mineralisation. The best drill intersection at Luhuma was $8.4 \mathrm{~m}$ of massive sulphide with a grade of $1.1 \% \mathrm{Ni}$ (Macheyeki, 2011), whereas at Rujungu it was $7 \mathrm{~m}$ of massive sulphide at $0.7 \% \mathrm{Ni}$ (Dwyka Resources, 2008).

\section{Musongati Nickel Laterite Deposit}

\section{Background}

From 1971 until 1986, the Burundian government carried out several exploration projects, funded by the UNDP and other agencies, to explore for Ni laterite and Ni sulphide at a number of prospects (Programme des Nations Unies pour le Développement, 1977, 1979; Deblond, 1994). These projects resulted in the delineation of three main Ni laterite deposits developed on ultramafic rocks: Musongati, Nyabikere and Waga (Table 2). The most important of these, the Musongati deposit, comprises three adjacent incised plateaux for which mineral resources were calculated separately: Buhinda, Rubara and Geyuka. The high-grade portion of the Buhinda plateau was the focus of a closely-spaced drilling campaign (128 drillholes on a 100 $\mathrm{m} \times 100 \mathrm{~m}$ spaced grid), to produce the first classified resource in the indicated category (Buminco, 1990). Since that time, recurrent political instability has limited further commercial development, but in 2008 a development licence for the Musongati deposit was issued to Burundi Mining and Metallurgy, a subsidiary of Samancor Nickel. 


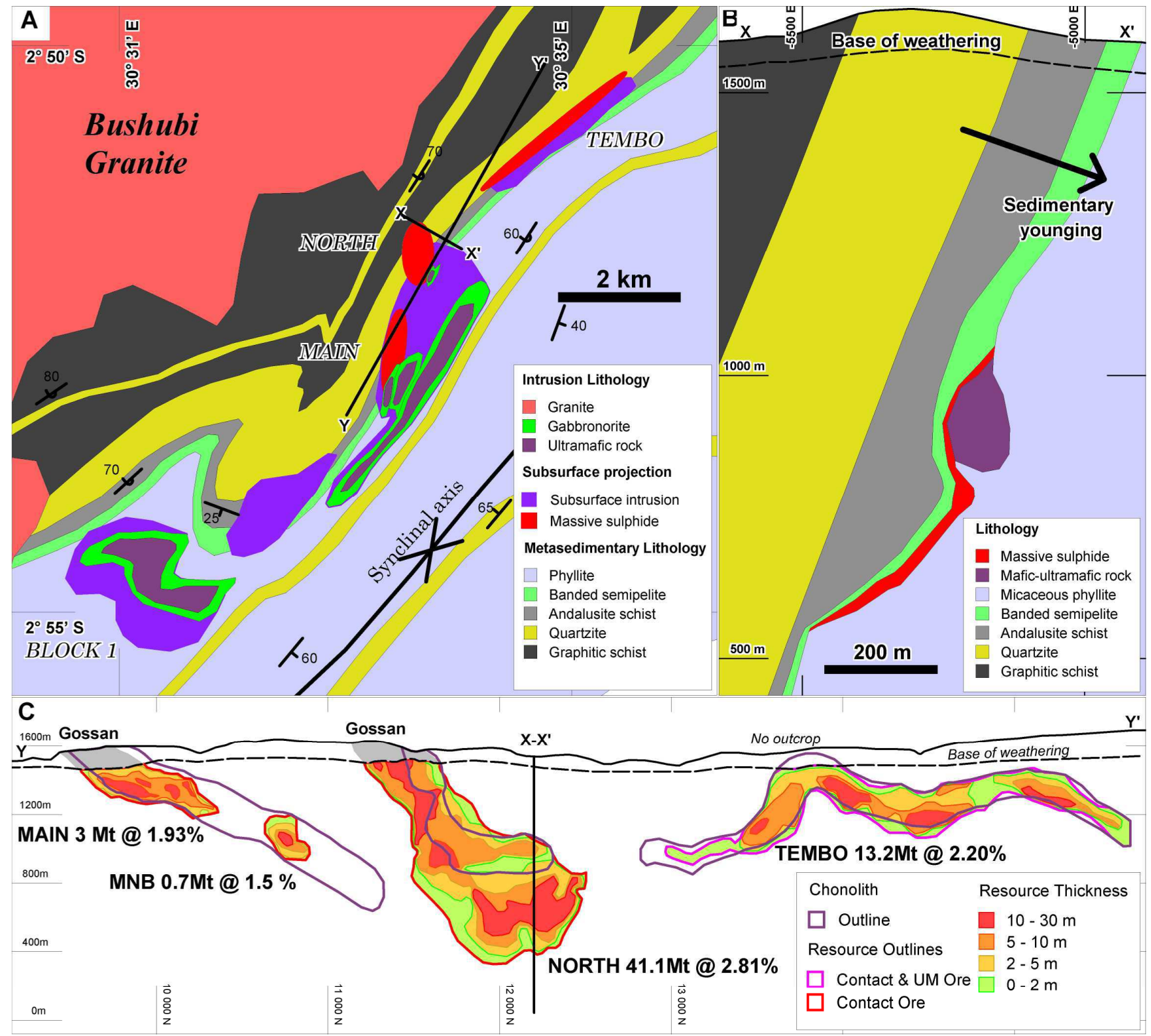

Figure 3. (A) Map of Kabanga prospect area, showing location of cross-section ( $X$ - $\left.X^{\prime}\right)$ and longitudinal section (Y-Y') figures, the positions of subsurface intrusions and massive sulphides projected to surface. (B) Cross section $X-X^{\prime}$ (local grid 12,200 m N) of Kabanga North. (C) Projected longitudinal section Y-Y'looking west showing massive sulphide true thickness contours and sinuous shape of chonoliths. Contact ore refers to external sulphide mineralisation and UM ore refers to internal sulphide mineralisation. Authors' interpretations from Evans et al. (1999), Lindsay (2007, 2010) and Maier et al. (2010).

Trial mining and processing was planned to start in 2014 (Anonymous, 2014).

\section{Deposit geology}

The Musongati intrusion has been emplaced into folded KaragweAnkole Belt (KAB) metasedimentary rocks near to a presumed deep crustal or lithospheric discontinuity (Fig. 1) (Tack et al., 1994, 2010). These metasedimentary rocks (Musongati Formation) are dominantly metapelites with a weakly-developed schistose fabric and are noted to be sulphidic (Fig. 4A). Most of the contacts at Musongati are poorly exposed and often tectonic in nature (Deblond, 1992). Locally, however, a recrystallized hornfels rock containing biotite poikiloblasts, cordierite and sillimanite, is developed around the intrusions and extends ten to fifty metres into the country rocks (Tack and Deblond, 1990).

The Musongati intrusion is divided into a lower Ultramafic Zone and an upper Mafic Zone, each with two main subzones (Deblond, 1994; Bandyayera, 1997). The Ultramafic Zone comprises the Peridotitic and Pyroxenitic subzones, in which olivine and orthopyroxene are the main cumulus minerals respectively. Euhedral chromite and anhedral interstitial sulphide grains also occur in minor amounts throughout. The Mafic Zone is subdivided into the lower Noritic and upper Gabbronoritic subzones, in which plagioclase becomes a major cumulus phase (Deblond, 1994; Bandyayera, 1997). Amphibole norite from the Mafic Zone at Musongati has been dated by SHRIMP analysis of zircons to $1374 \pm 14$ Ma by Tack et al. (2010). 
Table 3. The principal nickel prospects of the East African Nickel Belt, keyed to the location numbers in Figure 1.

\begin{tabular}{|c|c|c|c|c|c|c|c|c|}
\hline No. ${ }^{1}$ & Name & Sector & Discovery & Method $^{2}$ & Type & Activity $^{3}$ & Best result & Ref. \\
\hline 1 & Musongati & Central & 1972 & Map/Geochem & Laterite & Feasibility & Indicated Resource & $\mathrm{a}, \mathrm{b}$ \\
\hline 2 & Waga & Central & 1973 & Magn/Geochem & Laterite & Drilling & Inferred Resource & $\mathrm{a}$ \\
\hline 3 & Nyabikere & Central & 1972 & Map/Geochem & Laterite & Drilling & Inferred Resource & $\mathrm{a}$ \\
\hline 4 & Kabanga & North & 1974 & Magn/Geochem & Sulphide & Feasibility & Indicated Resource & $\mathrm{c}, \mathrm{d}$ \\
\hline 5 & Kapalagulu & South & 1962 & Map/Geochem & Laterite & Drilling & Inferred Resource & $\mathrm{e}$ \\
\hline 6 & Rutovu & Central & 1980 & Magn/Geochem & Sulphide & Scout drilling & Semi-massive suls & $\mathrm{f}$ \\
\hline 7 & Geyuka & Central & 1974 & Geochem & Sulphide & Scout drilling & Disseminated suls & $\mathrm{f}$ \\
\hline 8 & Nyabiraba & Central & 1975 & Magn/Geochem & Sulphide & Scout drilling & Disseminated suls & $\mathrm{f}$ \\
\hline 9 & Ranga South & Central & 1975 & Magn/Geochem & Sulphide & Scout drilling & Disseminated suls & $\mathrm{f}$ \\
\hline 10 & Muremera A & North & 1980 & Magn/Geochem & Sulphide & Scout drilling & Disseminated suls & g \\
\hline 11 & Muremera B & North & 1980 & Magn/Geochem & Sulphide & Scout drilling & Semi-massive suls & $\mathrm{g}$ \\
\hline 12 & Rujungu & North & 1984 & Magn/EM & Sulphide & Scout drilling & Massive sulphides & $\mathrm{g}$ \\
\hline 13 & Nyanzali & North & 1993 & Magn/EM & Sulphide & Scout drilling & Disseminated suls & $\mathrm{h}$ \\
\hline 14 & Luhuma (UN29-08) & North & 1976 & Magn/Geochem & Sulphide & Scout drilling & Massive sulphides & $\mathrm{i}$ \\
\hline 15 & Kibamba (UN296) & North & 1976 & Magn/Geochem & Sulphide & Scout drilling & Semi-massive suls & $\mathrm{j}$ \\
\hline 16 & Ruiza (UN18-01) & North & 1976 & Magn/Geochem & Sulphide & Scout drilling & Disseminated suls & $\mathrm{j}$ \\
\hline 17 & Burigi & North & 1995 & Magn/Geochem & Sulphide & Scout drilling & Disseminated suls & $\mathrm{j}$ \\
\hline 18 & Makambo & South & 1951 & Map/Geochem & Sulphide & Drilling & Semi-massive suls & $\mathrm{k}$ \\
\hline 19 & MC6 anomaly & South & 2005 & Magn/EM & Sulphide & Scout drilling & Semi-massive suls & $\mathrm{m}$ \\
\hline 20 & Ikulu Hill & South & 2006 & Map/Geochem & Sulphide & Chip sampling & Disseminated suls & $\mathrm{n}$ \\
\hline 21 & SE Lubalisi & South & 2006 & Map/Geochem & Sulphide & Chip sampling & Disseminated suls & $\mathrm{n}$ \\
\hline 22 & Mwese & South & 2006 & Map/Geochem & Sulphide & Chip sampling & Disseminated suls & $\mathrm{n}$ \\
\hline
\end{tabular}

1 - Refers to location in Fig. 1B, C; 2 - Discovery method(s); 3 - Most advanced exploration activity. Abbreviations: Geochem - geochemical survey; Magn magnetic survey; Map - surface mapping; EM - electromagnetic survey: suls - sulphides. References: a PNUD (1979); b Buminco (1990); c Barrick Gold (2007); d Glencore (2014); e Goldstream Mining (2005); f Deblond (1992); g Dwyka Resources (2008); h Maier et al (2010); i Macheyeki (2011); j Kabete (1996); k Goldstream Mining (2003); m Goldstream Mining (2006); n IMX Resources (2011).

The olivine-rich rocks of the Peridotitic and Pyroxenitic Subzones described above are often pervasively altered to serpentine and magnetite along a reticulated fracture network (Bandyayera, 1997). The timing and abundance of this serpentinization is an important consideration for the depth and intensity of lateritization, as well as in exploration, when considering the direction and intensity of natural remnant magnetism of the rock.

\section{Description of mineralisation}

The Musongati Ni laterite deposit was formed by prolonged weathering, since at least the Miocene, of the ultramafic rocks above a fluctuating water table. The progressive breakdown of olivine, sulphide and serpentine during this weathering liberated $\mathrm{Ni}, \mathrm{Cu}$ and $\mathrm{Co}$, which were then concentrated in stable weathering products underneath a lateritic capping and leached zone (Golightly, 1981). At Musongati, the laterites were derived from weathering of the serpentinized dunites and harzburgites of the Peridotite Subzone, which have primary nickel contents of about 0.25 to $0.5 \% \mathrm{Ni}$.

The Burundian laterites conform to a standard profile (Fig. 4B) commencing with either a soil or duricrust (residual ferricrete, ironcap, canga or cuirasse) at the top, followed by a limonite or ferralite zone consisting primarily of goethite, clays and occasional residual rock fragments. At the base of the profile is the saprolite zone in which the main nickel concentrations occur. $\mathrm{Co}, \mathrm{Cu}$ and PGE are mainly concentrated in the goethite of the limonite zone with lower concentrations of $\mathrm{Ni}$ (Bandyayera, 1997; Maier et al., 2008). Nickel is associated with goethite in the limonite ore, whereas in the saprolite ore it is contained in a variety of Ni-rich clays (pimelite and nontronite), serpentine group minerals (chrysotile and antigorite) and talc minerals (Bandyayera, 1997). Discrimination between the limonite (higher than $38 \% \mathrm{Fe}$ ) and saprolite (lower than $38 \% \mathrm{Fe}$ ), zones can also be made on a geochemical basis (Fig. 4B) (Programme des Nations Unies pour le Développement, 1977, 1979). The two types of mineralisation, limonite and saprolite, occur in approximately equal proportions (Programme des Nations Unies pour le Développement, 1977).

Weak base metal sulphide mineralisation is documented within the Ultramafic Zone of the Musongati intrusion, as well as other related intrusions along the KMA line. This varies from fine-grained, weakly disseminated sulphides (pentlandite > pyrrhotite) throughout the Buhinda and Rubara dunites and peridotites, to greater concentrations of coarser interstitial sulphides (pyrrhotite > pentlandite), that are found in the harzburgites and pyroxenites of the Geyuka unit (Deblond, 1994; Bandyayera, 1997; Maier et al., 2008). In some localities such as Rutovu, net-textured and semi-massive sulphides have been observed and commonly develop near the footwall margins of the intrusions (Table 3) (Deblond, 1992).

\section{The Southern Sector: The Kapalagulu Intrusion}

Commercial exploration of the Kapalagulu intrusion commenced in the 1950s, and continues today, with several encouraging prospects having been discovered. The Kapalagulu intrusion and other 

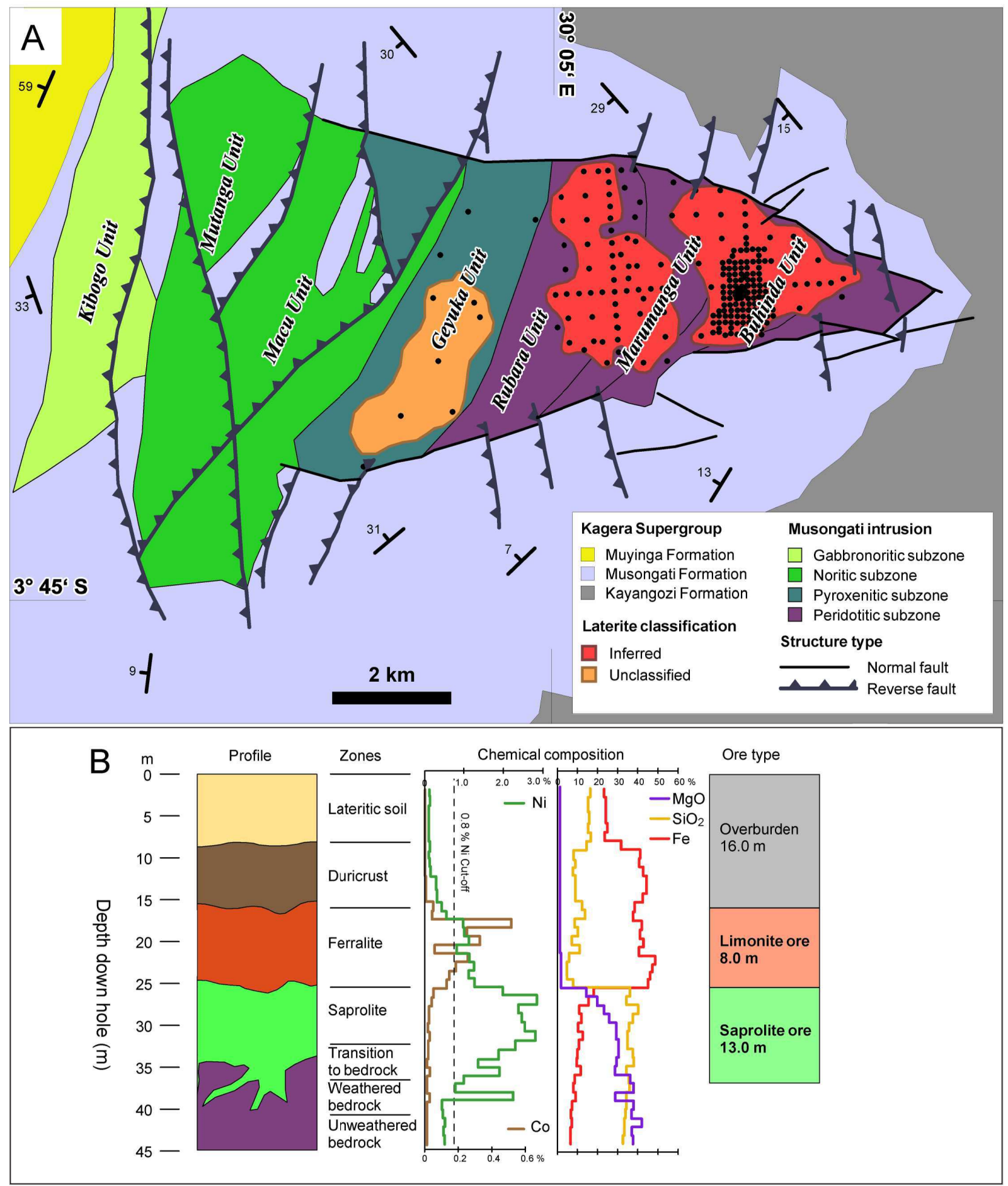

Figure 4. (A) Geological interpretation of the Musongati intrusion showing lateritic mineral resource outlines and evaluation drill holes (black dots) overlaid on igneous subzones. Authors' interpretation based on Deblond (1992) and 1:100,000 scale geological maps published by the Burundi government. (B) Schematic section of a lateritic profile and chemical variations from the Buhinda plateau (after Buminco, 1990).

dyke-like satellite bodies related to it are believed to have been emplaced at $1392 \pm 26 \mathrm{Ma}$ (Maier et al., 2007), into amphibolite facies biotite-garnet-kyanite schists and gneisses of the dominantly metasedimentary Wansisi series of the Wakole Terrane (Fig. 1C) (Boniface et al., 2014).

Nickel mineralisation of both laterite and sulphide type is known from the Kapalagulu intrusion, a deformed layered intrusion with lithologies similar to those of the Musongati intrusion in Burundi (Maier et al., 2008). Three main types of mineralisation have been identified within the mafic-ultramafic rocks of the Kapalagulu Intrusion and its marginal bodies. These are the lateritic enrichment of nickel $(\mathrm{Ni})$, copper $(\mathrm{Cu})$, cobalt $(\mathrm{Co})$ and platinum group elements (PGE) over the main outcrop of the Ultramafic Zone of the Lubalisi and Lubalisi Extension Sectors; PGE mineralisation associated with 
thin and discontinuous sulphidic chromitite seams within the lower part of the ultramafic Basal Zone at Lubalisi and disseminated to massive textured $\mathrm{Ni}-\mathrm{Cu}$ bearing sulphides within the upper olivine cumulates of the Basal Zone and within associated marginal bodies (Table 3). A good overview of the mineralisation is provided by Wilhelmij and Cabri (2015).

\section{Summary and Discussion}

\section{Theories on the origin of the deposits}

The Ni laterite deposits of the EANB were generated much in the same manner that has been described for the classic laterite deposits of New Caledonia, Cuba or the Philippines (Golightly, 1981). Most of the nickel derives from the intense tropical weathering of olivine-rich lithologies such as dunite, harzburgite or serpentinite, in which nickel substitutes for magnesium in small quantities. With the variation of the water table during alternate wet and dry seasons, or wetter and drier long term periods, nickel is leached from the nearsurface layers of oxidized rock and carried downwards to precipitate in newly forming nickel-rich iron hydroxides in the ferralite zone and clay, talc and serpentine-like minerals in the saprolite zone. Given sufficient time and a very stable tectonic environment, such as occurred in central Africa during the Mesozoic and Cainozoic, important concentrations of nickel can be built up in the saprolitic and ferralitic zones of the weathering profile (Bandyayera, 1997).

Unlike the ultramafic protoliths of most currently exploited $\mathrm{Ni}$ laterite deposits, which are developed on the mantle section of ophiolites, the protoliths of the EANB laterites are derived from sulphide-bearing layered intrusions, and are thus already enriched in copper and platinum group elements, as well as nickel and cobalt. The PGE and $\mathrm{Cu}$ are preferentially enriched in the ferralite zone, along with $\mathrm{Co}$, whereas $\mathrm{Ni}$ is preferentially enriched in the saprolite zone. However, it is not yet known whether these other metals can be extracted commercially with the $\mathrm{Ni}$.

The mode of formation of large magmatic Ni sulphide deposits is well understood now (Naldrett, 2004) and can be summarized as follows. Nickel is released from the mantle by large-degree partial melting and is carried up in primitive (picritic or komatiitic) magmas (Arndt et al., 2005) along deep lithospheric-scale structures (Begg et al., 2010). In the crust, these superheated magmas interact with crustal material, resulting in selective or bulk assimilation and contamination of the magma. This interaction causes sulphur to exceed its saturation limit in the contaminated magma, and it then forms a fine emulsion of a separate immiscible molten sulphide liquid in the silicate magma, like the suspension of oil droplets in vinegar of a salad dressing. The chalcophile elements, particularly nickel, copper and the PGE, preferentially partition into the sulphide liquid (Naldrett, 2004). The sulphide liquid has different density and viscosity characteristics to the silicate magma and thus fluid dynamic processes can lead to physical segregation and enrichment of the molten sulphide and its emplacement as discrete massive sulphide bodies, either within or at the base of its parental intrusive body, or in the adjacent host rocks (Naldrett, 1999; Gauert, 2001; Arndt et al., 2005). After solidification and cooling, the sulphide crystallizes into its low-temperature mineralogy comprising pyrrhotite $\left(\mathrm{Fe}_{1-\mathrm{x}} \mathrm{S}\right)$, pentlandite $\left((\mathrm{Ni}, \mathrm{Fe})_{9} \mathrm{~S}_{8}\right)$ and chalcopyrite $\left(\mathrm{CuFeS}_{2}\right)$. This general model can be applied successfully to the Ni sulphide mineralisation of the EANB (Maier $e t$ al., 2011).

\section{Styles of sulphide mineralisation and formation of economic deposits}

Within the EANB there are two main styles of Ni sulphide mineralisation: (1) weak disseminations ( 0.5 to 10 modal \%) of sulphides in all bodies including the large, lopolithic layered intrusions, and (2) high relative abundances (40 to 100 modal \%) of net-textured to massive sulphide found mainly in the small, chonolithic tube-like sill (or dyke) intrusions. It should be emphasized that all of the ultramafic-bearing EANB intrusions (those with olivine and pyroxene cumulates) contain medium to large tonnages of magmatic sulphides of the first style, however, these are all uneconomic due to their low grades $(<1 \% \mathrm{Ni})$. Only a handful of chonolith intrusions are known to contain mineralisation of the second style. Kabanga is currently the only one of these intrusions with potentially economic Ni sulphides. We will discuss here what characteristics make Kabanga potentially economic, how these originated and whether there could be other rich deposits still to be found.

Essentially, the Kabanga deposit is valuable because it has both a sufficient tonnage $(>50 \mathrm{Mt})$ to warrant the necessary capital expenditure, and a high Ni grade (2.6\%) that would ensure low mining, milling and concentration costs, relative to the value of the concentrate product (Glencore, 2014; Mudd and Jowitt, 2014). The high grade at Kabanga is due to a combination of the high abundance of sulphide in the rock ( 75 to 100 modal \%) and the relatively high tenor of these sulphides ( 2 to $4 \%$ in $100 \%$ sulphides). Neither of these features is common in the other intrusions.

At this point, it is important to define some terms that are used in magmatic sulphide geology to help in understanding their genesis, but also that have relevance for development planning of mining methods and metallurgical beneficiation. The grade of a rock or deposit means the absolute content of the metal of interest (e.g. Ni) in the rock, as measured by standard whole-rock assaying methods. The tenor of a mineralised rock comprising a mixture of sulphides and silicates means the metal content of the sulphide component only (Naldrett, 2004). This distinction between tenor and grade is important in understanding magmatic sulphide deposits, as most are derived from the variable unmixing of an emulsion of distinct sulphide and silicate melts. The tenor is mainly controlled by the high-temperature geochemistry of the sulphide-silicate emulsion, whereas the grade is controlled by the physical separation and concentration of these molten sulphides during the flow and emplacement of the liquid sulphide and magma mixture. Practically, the tenor is estimated from the measured metal grade and sulphur (S) content by recalculation to $100 \%$ sulphides using a specific formula or procedure (Naldrett, 2004) that is appropriate for the range of rock types being considered and that takes into account the metal bound in silicates (e.g. Ni in olivine). Another way of envisaging Ni tenor that is useful for metallurgical studies, is to estimate the pentlandite to pyrrhotite ratio of the sulphides by modal mineralogical analysis.

The high abundance of sulphides at Kabanga and at other chonolith intrusions with style 2 mineralisation can be explained by massive incorporation of barren sedimentary sulphides (mainly pyrrhotite) into the magma during ascent and emplacement. Based on lithogeochemistry, Maier et al. (2010) estimated that the magma at Kabanga had incorporated up to 20 to $30 \%$ of S-bearing sedimentary material by bulk assimilation. Their sulphur isotope data shows that more than $50 \%$ of the sulphur in the deposit was derived 
from the sedimentary rock. It is this high degree of incorporation of sedimentary sulphides at an early stage of the magma emplacement, together with subsequent physical concentration during entrainment in irregular, constricted channels (Evans-Lamswood et al., 2000), that has resulted in the high proportion of net-textured and massive sulphides (style 2) within the intrusions at Kabanga.

Normally this level of assimilation would imply a low silicate to sulphide liquid ratio (R-factor), resulting in low metal tenors of the sulphide (Campbell and Naldrett, 1979; Evans et al., 1999; Maier and Barnes, 2010). The addition of large amounts of barren (Ni-Cupoor) sedimentary sulphide in a relatively small volume of silicate magma acts to dilute the associated magmatic sulphides, thus reducing the Ni tenor of the sulphides. In effect, the limited quantity of nickel brought up from the mantle in a batch of magma is spread within a larger quantity of molten sulphide. In fact, this is the case for most of the other small intrusions that contain style 2 massive sulphides, such as the Luhuma and Rujungu chonoliths, whose sulphides have tenors of about $1.1 \% \mathrm{Ni}$ and $0.8 \% \mathrm{Ni}$ respectively.

Another mechanism is required to explain the simultaneous high proportion of massive sulphides with relatively high tenor (2.0 to $3.5 \% \mathrm{Ni}$ in sulphides) at Kabanga. Maier and Barnes (2010) and Maier et al. (2011), proposed a mechanism for upgrading sulphidebearing magma within the conduits of the smaller chonoliths such as Kabanga North and Tembo, whereby repeated pulses of magma scavenged metals from earlier-emplaced dense sulphide pools with more Ni-rich compositions. Similarly, Kerr and Leitch (2005) propose that a later batch of primitive S-undersaturated magma in the conduit can redissolve earlier-formed trapped sulphides, thereby upgrading metal tenors. The passage of multiple pulses of magma through individual conduits at Kabanga suggests a structural focussing mechanism, such as intersection of fractures with a deep lithospheric boundary (Begg et al., 2010). Thus there are several factors that are necessary to upgrade the size or quality (grade/tenor) of a mineralised body, and only those few intrusions that have experienced all or most of these factors are likely to be economic. These factors may not be unique to Kabanga, but future exploration in the belt must take account of these constraints when evaluating results from empirical exploration methods.

\section{Exploration methodologies and success rates}

Exploration for the Ni laterite deposits of the EANB has been relatively straightforward. The formation of these deposits by weathering of ultramafic portions of large layered intrusions means they are necessarily large and exposed at surface, making their discovery by standard regional geochemical survey methods quite straightforward. Additionally, their parent rocks are olivine-rich, often serpentinized and thus make large intense magnetic anomalies that can be easily identified by airborne magnetic surveys. All the major laterite deposits were discovered within 2 or 3 years of the commencement of exploration in Burundi, and it is unlikely that any large deposits remain to be discovered.

In contrast, exploration for high-grade Ni sulphide deposits in the EANB has proven to be rather difficult and expensive. After the initial discovery of massive sulphides at the Kabanga Main intrusion in 1978, the next major discovery was in 1993 at Kabanga North, and Tembo was only found in 2006, after years of near-continuous exploration effort. There are a number of difficulties in exploring for high-grade Ni sulphides, some of which are fairly frequently encountered worldwide, whereas others are specific to the EANB. These can be listed as follows:

- The economic massive sulphide mineralisation has a small "footprint" area, due to the upright folding style which has resulted in most bodies being steeply plunging.

- High grade mineralisation does not necessarily have a widespread "halo" of low-grade mineralisation or alteration, as it often occurs in small, discrete chonolith bodies.

- There are a large number of strong magnetic anomalies in the region due to the predominance of ferromagnetic minerals in both ultramafic rocks (magnetite from olivine alteration) and host metasedimentary rocks (monoclinic pyrrhotite laminae).

- The sedimentary pyrrhotite laminae and graphitic horizons can be strongly conductive in some structural circumstances, leading to large numbers of false anomalies in airborne EM surveys.

- The strong tropical weathering has mobilized the elements of interest in the lateritic profile and resulted in strongly leached true gossans and a multitude of false "gossans" derived from ultramafic and Fe-rich metasedimentary rocks.

- Subsequent drainage incision due to recent tectonics has led to strong contrasts of geochemical background levels between different regolith regimes, making the identification of real anomalies more difficult.

The optimum direct detection method for massive sulphide mineralisation is based on its very high conductivity. On the regional scale, however, airborne EM surveys, which necessarily operate at medium to high frequencies $(>20 \mathrm{~Hz})$, have been ineffective in distinguishing "superconductors" such as massive Ni sulphide bodies, from structurally-controlled barren metasedimentary conductors (Wolfgram and Golden, 2001). The most effective airborne geophysical method for regional-scale exploration has proven to be relatively close-spaced magnetic surveys, combined with high resolution radiometric measurement, which can reliably detect olivine and sulphide-bearing ultramafic rocks at surface and to depths of $500 \mathrm{~m}$. The airborne anomalies have to be followed-up on the ground and for this, low-frequency time-domain EM techniques, particularly those methods adapted for measuring response from "superconductors", such as the UTEM system and the step-response measurement pulse EM systems (Ravenhurst, 2001), are still the best on a prospect-scale.

Apart from the initial regional exploration carried out by governmental agencies in the 1970s, geochemical methods have tended to be used in a secondary role to airborne and ground geophysical methods, for verification or ranking of magnetic or EM targets. Geochemical identification of mineralised intrusions has generally relied on standard aqua regia digestions of soil and stream sediment media and multi-element analysis by inductively coupled plasma (ICP)-atomic emission spectrometry, with anomalies being signalled by coincident $\mathrm{Ni}-\mathrm{Cu}-\mathrm{Co}$ highs. Modern partial digest techniques and low-level analysis of the PGE and Au by ICP-mass spectrometry, do show promise in distinguishing higher tenor magmatic sulphide mineralisation from lower tenor sulphide and ultramafic-dominated geochemical signatures but have not been tested in the EANB.

In summary, exploration for $\mathrm{Ni}$ sulphide deposits in the EANB has been most successful using a combination of airborne magnetic surveys to locate the olivine-rich bodies that invariably accompany sulphides, and ground EM methods supplemented by geochemistry 
to locate the actual massive sulphides. As always, a thorough knowledge of regional and local geology is needed to interpret the anomalies generated by these methods.

\section{Development potential of the EANB}

Neither the large laterite at Musongati, nor the large sulphide deposit at Kabanga has yet been developed, to the continuing chagrin of the host countries. Their development has been consistently postponed because of inadequate regional infrastructure, in particular the lack of a sufficient and reliable power provision in the region, and because of the poor state of transport links to the coast, some 1,200 km away (Lindsay, 2010). Other negative factors weighing against the early development of the deposits have been political upheaval in Burundi, the negative public perception of large-scale foreign-owned mining operations in Tanzania, the lack of trained and experienced managers and operators for large, mechanized open-pit or underground mining operations in both host countries, and the commercial uncertainty in the global nickel market, posed by the rise in production of relatively cheap nickel pig-iron in China since 2007 (Lennon, 2007). However, development of both laterite and sulphide deposits is mainly contingent on the enhancement of the power supply and transport links to this land-locked region.

A Ni laterite project in Burundi could only be viable producing more than, or equal to, $30 \mathrm{kt}$ of $\mathrm{Ni}$ a year to obtain the economies of scale (Dalvi et al., 2004). Buminco (1990) has estimated that an electric power supply of $80 \mathrm{MW}$ would be required for a $30 \mathrm{kt}$ high pressure acid leach production facility at Musongati, in addition to large quantities of locally-available peat to fire boilers in the acid plant and a magnesium oxide plant. Road or rail links to Burundi and northwestern Tanzania would have to be enhanced to handle the sizable quantities of raw materials coming into and out of the country. The long-planned extension of the Central corridor route from the existing railhead at Isaka in Tanzania, to Kigali and Gitega, would be crucial in this regard (Anonymous, 2012).

Although the Kabanga deposit is acknowledged to be one of the largest and richest undeveloped $\mathrm{Ni}$ sulphide deposits known at present, and, although a full draft feasibility study was completed in 2014, there are no plans to develop the Kabanga deposit in the immediate future, and no timetable has been released for its development by the joint venture partners. The Kabanga deposit is held under a retention licence, originally granted in 2009 and renewed in 2014 for a further 5 years (Glencore, 2014).

Against this relatively pessimistic outlook must be set the veritable progress in both large-scale mining (of gold) and in infrastructure development in Tanzania. The government with bilateral and multilateral partners has made real progress in extending the national electricity grid to Mwanza and the Lake Victoria goldfields, and key road links from Dodoma to Mwanza and from the rail head at Isaka to Rwanda and Burundi have been upgraded to all-weather surfaces. The African Development Bank is the lead financier for a scheme to extend the existing Dar es Salaam - Isaka central railway to Kigali in Rwanda and Gitega in Burundi, which would have it passing close to the Kabanga and Musongati areas (Anonymous, 2012). Additionally, Tanzania is planning to develop an 80 MW hydro-electric scheme on the Kagera River at the Rusumo Falls, in conjunction with its neighbours Burundi and Rwanda (Nile Basin Initiative, 2014).

In the recent economic climate (2010-2015), with uncertainty about the demand level from Asian markets, and the availability of cheap nickel pig iron production, investment decisions on these highrisk deposits have been postponed. If this situation changes, and if the above-described infrastructure projects come to fruition, then these deposits and others that have yet to be discovered in the belt, will be well placed to meet future demand from Asian and other markets.

\section{Acknowledgements}

The authors wish to record their debt to the many governmental, company and academic geologists and engineers that have worked on and carefully accrued the data on which this review is based. We also acknowledge the management of companies who retain interests in mineral rights on the ground in the East Africa Nickel Belt for their kind permission to publish aspects of their exploration work. Notably we thank Phil Hoskins, Acting CEO of IMX Resources (Perth) and Kevin Olshefsky of Kabanga Nickel Company Limited (Dar es Salaam). We are grateful to Mike Wilson and Luke Longridge for their judicious reviews of the initial manuscript and to Andy Killick and the editor for later suggestions.

\section{References}

African Rainbow Minerals (2014). ARM Integrated Annual Report 2014. Downloaded from corporate website on 17/02/2015 from: http://arm.integrated-report.com/2014/.

Ambatovy, J.V. (2014) Historique. Ambatovy Project website, accessed on 27/01/2015 from: http://www.ambatovy.com/docs/ ?lang $=$ fr \& $\mathrm{p}=166$.

Anderson, I. G. (1986). The Empress nickel deposit, Zimbabwe. In: C. R. Anhaeusser and S. Maske (Editors), Mineral Deposits of Southern Africa Volumes I and II, Geological Society of South Africa, Johannesburg, 231-236.

Anglo American Platinum (2014). Anglo American Platinum Limited Annual Results Presentation 2014. Downloaded from corporate website on 17/02/2015 from: http://www.angloamerican platinum.com/ /media/Files/A/Anglo-American-Platinum/ annual-reports/aap-annual-results-presentation-2014.pdf .

Anonymous (2012). Rwanda railway "evaluation" to begin. Railways Africa magazine, March 6, 2012, Rwanda. Downloaded on 27/ 01/2015 from: http://www.railwaysafrica.com/blog/2012/03/06/ rwanda-railway-\%E2\%80\%9Cevaluation\%E2\%80\%9D-tobegin/.

Anonymous (2014). Logistic headache for Koncar at Musongati. Africa Mining Intelligence on-line magazine, No. 330, Oct. 10, 2014. Downloaded on 14/10/2014 from: http://www.africa intelligence.com/AMA/exploration-production/2014/10/14/ logistic-headache-for-koncar-at-musongati,108042505-GRA.

Arndt, N. T., Lesher, C. M. and Czamanske, G. K. (2005). Mantlederived magmas and magmatic Ni-Cu-(PGE) deposits. In: J.W. Hedenquist, J. F. H. Thompson, R.J. Goldfarb, and J.P. Richards (Editors), Economic Geology $100^{\text {th }}$ Anniversary Volume, Society of Economic Geologists: Littlewood, U.S.A., 5-21.

Bandyayera, D. (1997). Formation de laterites nickelifères et mode de distribution des éléments du groupe du platine dans les profils latéritiques du complexe de Musongati, Burundi. PhD thesis (unpubl.), Université du Québec à Chicoutimi, 440 pp.

Barrick Gold (2007). Barrick and Xstrata Announce Significant Developments at Kabanga Nickel Project. Press release dated 15 February 2007, accessed from Barrick Gold Corporation website on 22/01/2010 from: http://www.barrick.com/investors/news/ news-details/2007/BarrickandXstrataAnnounceSignificant DevelopmentsatKabangaNickelProject $1520071200902 /$ 
default.aspx.

Bamangwato Concessions Ltd. (2014). Resources and Reserves as at 31 June 2011. Corporate website, accessed on 27/01/2015 from: http://www.bcl.bw/index.php?id=29.

Begg, G. C., Hronsky, J. A. M., Arndt, N. T., Griffin, W. L., O'Reilly, S. Y. and Hayward, N. (2010). Lithospheric, cratonic and geodynamic setting of Ni-Cu-PGE sulfide deposits, Economic Geology, 105, 1057-1070.

Boniface, N., Schenk, V. and Appel, P. (2014). Mesoproterozoic highgrade metamorphism in pelitic rocks of the northwestern Ubendian Belt: Implication for the extension of the Kibaran intra-continental basins to Tanzania. Precambrian Research, 249, 215-228.

Buminco (1990). Projet Nickel de Musongati: Etude de Reactualisation. Unpublished internal report by Buminco and Lonmin PLC for Government of Burundi, pp.

Bursill, C. (1959). Intensive search for minerals in Central Africa. Optima, 2(2), 27-35.

Cahen, L., Delhal, J., Vail, J. R., Bonhomme, M., Ledent, D. (1984). The geochronology and evolution of equatorial Africa. Clarendon Press, Oxford, 495 pp.

Campbell, I. H. and Naldrett, A. J. (1979). The influence of silicate:sulfide ratios on the geochemistry of magmatic sulfides. Economic Geology, 74, 1503-1505.

Cawthorn, R. G. (1999). The platinum and palladium resources of the Bushveld Complex: platinum in South Africa. South African Journal of Science, 95, 11/12, 481-489.

Chimimba, L. R. (1986). The Madziwa nickel-copper deposits, Zimbabwe. In: C. R. Anhaeusser and S. Maske (Editors), Mineral Deposits of Southern Africa Volumes I and II, Geological Society of South Africa, Johannesburg, 237-241.

Chimimba, L. R. and Ncube, S. M. N. (1986). Nickel sulphide mineralization at Trojan mine. In: C. R. Anhaeusser and S. Maske (Editors), Mineral Deposits of Southern Africa Volumes I and II, Geological Society of South Africa, Johannesburg, 249-253.

Combe, A. D. (1932). The geology of south-west Ankole (and adjacent territories with special reference to the tin deposits). Memoir, Geological Survey of Uganda, II, 236 pp, with Appendix on Petrology by A. W. Groves.

Dalvi, A.D., Bacon, G. and Osborne, R. (2004). The Past and Future of Nickel Laterites. Abstract at Prospectors and Developers Association of Canada 2004 International Convention, March 710, 2004.

Deblond, A. (1992). Etude géologique des massifs gabbroïques de l'est du Burundi - Rapport Final en 5 Fascicules. Administration Générale de Coopération et Développement du Burundi, BDI : CI 14497/11.

Deblond, A. (1994). Geologie et petrologie des Massifs basiques et ultrabasiques de la ceinture Kabanga-Musongati au Burundi. Musée Royal de L'Afrique Centrale, Annales, Sciences Geologiques, 99, 123 pp.

Deblond, A. and Tack, L. (1999). Main characteristics and review of mineral resources of the Kabanga-Musongati mafic-ultramafic alignment in Burundi. Journal of African Earth Sciences, 29, 313328.

De Waal, S. A. (1986). The Bon Accord nickel occurrence at Barberton.. In: C. R. Anhaeusser and S. Maske (Editors), Mineral Deposits of Southern Africa Volumes I and II, Geological Society of South Africa, Johannesburg, 287-291.

Duchesne, J-C., Liégeois, J-P., Deblond, A. and Tack, L. (2004). Petrogenesis of the Kabanga-Musongati layered mafic-ultramafic intrusions in Burundi (Kibaran Belt): geochemical, Sr-Nd isotopic constraints and $\mathrm{Cr}-\mathrm{Ni}$ behaviour. Journal of African Earth Sciences, 39, 133-45.

Dwyka Resources (2008). Muremera Nickel Project intersects Nickel in Second Phase Drilling. Corporate press release dated $27^{\text {th }}$ October 2008, accessed 27/01/2015 from 24hgold website: http:/ /www.24hgold.com/francais/article-compagnie-or-argentmuremera-nickel-project-intersects-nickel-in-second-phasedrilling. aspx ?articleid $=334576$.

Evans, D. M., Byemelwa, L. and Gilligan, J. (1999). Variability of magmatic sulphide compositions at the Kabanga nickel prospect, Tanzania. Journal of African Earth Sciences, 29, 329-351.

Evans, D. M., Boadi, I., Byemelwa, L., Gilligan, J. M., Kabete, J. and Marcet, P. (2000). Kabanga magmatic nickel sulphide deposits, Tanzania - morphology and geochemistry of associated intrusions. Journal of African Earth Sciences, 30, 651-674.

Evans-Lamswood, D. M, Butt, D. P., Jackson, R. S., Lee, D. V., Muggridge, M. G., Wheeler, R. I. and Wilton, D. H. C. (2000). Physical controls associated with the distribution of sulfides in the Voisey's Bay Ni-Cu-Co deposit, Labrador. Economic Geology, 95, 749-769.

Fernandez-Alonso, M., Cutten, H., de Waele, B, Tack, L., Tahon, A., Baudet, D. and Barritt, S. D. (2012). The Mesoproterozoic Karagwe-Ankole Belt (formerly the NE Kibara Belt): the result of prolonged extensional intracratonic basin development punctuated by two short-lived far-field compressional events. Precambrian Research, 216-219, 63-86.

First Quantum (2014). Enterprise. Corporate website of First Quantum Minerals Ltd., accessed on 27/01/2015 from: http://www.firstquantum.com/Our-Business/Development-Projects/Trident/ Enterprise/default.aspx.

Gandini, J. (2011). Ouarzazate au temps du Protectorat: La Mine de Bou-Azzer. Personal website last updated 15/08/2011, accessed 09/02/2015 from: http://www.ouarzazate-1928-1956.com/lesmines/la-mine-de-bou-azzer.html.

Gauert, C. (2001). Sulphide and oxide mineralisation in the Uitkomst Complex, South Africa: origin in a magma conduit. Journal of African Earth Sciences, 32, 149-161.

Glencore (2014). GlencoreXstrata Resources \& Reserves as at 31 December 2013. Downloaded on 27/01/2015 from Glencore website: http://www.glencore.com/investors/reports-and-results/ reserves-and-resources/.

Goldstream Mining (2003). Goldstream/Lonmin finish 2003 field season on a high note. Press release dated $9^{\text {th }}$ December 2003, accessed on 03/02/2015 from Infomine: http://www.infomine. com/index/pr/Pa156534.PDF.

Goldstream Mining (2005). JORC Resource for Goldstream Mibango Joint Venture Project . Press release dated 7 April 2005, accessed from IMX Resources Ltd website on 10/08/2005 from: http:// www.imxresources.com.au/investors-and-media/asxannouncements/archive/listing.

Goldstream Mining (2006). New Style of Massive Nickel Sulphide Mineralisation Discovered at Mibango, Tanzania. Press release dated 21 September 2006, accessed from IMX Resources Ltd website on 24/01/2013 from: http://www.imxresources.com.au/ investors-and-media/asx-announcements/archive/listing.

Golightly, J. P. (1981). Nickeliferous laterite deposits. In: B. J. Skinner, (Editor) Economic Geology 75th Anniversary Volume 1905-1980, Society of Economic Geologists, Littleton, CO, USA, 710-735.

Gordon, P. S. L. (1973). The Selebi-Pikwe nickel-copper deposits, Botswana. Special Publication, Geological Society of South Africa, 3, 167-187.

Grey, I. M. (1967). Geological Map with Explanation, Quarter Degree Sheet 29 and 29W, Ngara; 1:125,000. Mineral Resources Division, Dodoma, Tanzania.

Impala Platinum (2014). Implats Mineral resources and reserves statement 2014. Downloaded from corporate website on 17/02/ 2015 from: http://www.implats.co.za/implats/downloads/2014/ 
ImplatsM\&R2014.pdf.

IMX Resources (2011). IMX Continues to Discover Sulphide Bearing Intrusions at the Mibango Project in Tanzania. Press release dated 14 April 2011, accessed from IMX Resources Ltd website on 06/ 07/2011 from: http://www.imxresources.com.au/investors-andmedia/asx-announcements/archive/listing.

Johnson, R. S. (1986). The Phoenix and Selkirk nickel-copper sulphide ore deposits, Tati greenstone belt, Eastern Botswana. In: C. R. Anhaeusser and S. Maske (Editors), Mineral Deposits of Southern Africa Volumes I and II, Geological Society of South Africa, Johannesburg, 243-248.

Kabete, J. M. (1996). Summary of work completed on Reconnaissance License \#5/92 Kagera Region by BHP Minerals International Exploration Inc. Unpublished reports submitted to Ministry of Energy and Mines, United Republic of Tanzania.

Kerr, A. and Leitch, A. M. (2005). Self-destructive sulfide segregation systems and the formation of high-grade magmatic ore deposits. Economic Geology, 100, 311-322.

Kokonyangi, J., Kampunzu, A. B., Armstrong, R., Yoshida, M., Okudaira, T., Arima, M. and Ngulube, D. A. (2006). The Mesoproterozoic Kibaride belt (Katanga, SE D. R. Congo). Journal of African Earth Sciences, 46, 1-35.

Lennon, J. (2007). The Chinese nickel outlook and the role of nickel pig iron. Presentation given to International Nickel Study Group, May 11, 2007: accessed on 27/01/2015 from: http://www.insg.org/ presents/Mr_Lennon_May07.pdf.

Lindsay, C. (2007). Kabanga Nickel Project. Presentation to CanadaAfrica Mining Procurement Seminar, Montreal, May 2nd, 2007. Downloaded on 28/08/2009 from Xstrata Nickel website.

Lindsay, C. (2010). Kabanga Nickel Project. Presentation to Ausmine, Perth, Australia, December 1st, 2010. Downloaded on 27/01/2015 from: http://www.austmine.com.au/Portals/25/Content/ Downloads/Austmine $\% 20$ Networking $\% 20$ Series $\% 20$ Presentations/AusminePresentation_XstrataNickel_Kabanga Project_01Dec2010.pdf

Macheyeki, A. S. (2011). Application of lithogeochemistry to exploration for Ni-Cu sulfide deposits in the Kabanga area, NW Tanzania. Journal of African Earth Sciences, 61, 62-81.

Maier, W. D. and Barnes, S-J. (2010). The Kabanga Ni sulfide deposits, Tanzania: II. Chalcophile and siderophile element geochemistry. Mineralium Deposita, 45, 443-460.

Maier, W. D., Peltonen, P. and Livesey, T. (2007). The ages of the Kabanga North and Kapalagulu intrusions, Western Tanzania: a reconnaissance study. Economic Geology, 102, 147-54.

Maier, W. D., Barnes, S-J., Bandyayera, D., Livesey, T. and Ripley, E. (2008). Early Kibaran rift-related mafic-ultramafic magmatism in western Tanzania and Burundi: Petrogenesis and ore potential of the Kapalagulu and Musongati layered intrusions. Lithos, 101, 24-53.

Maier, W. D., Barnes, S-J., Sarkar, A., Ripley, E., Li, C. and Livesey, T. (2010). The Kabanga Ni sulfide deposit, Tanzania: I. Geology, petrography, silicate rock geochemistry, and sulphur and oxygen isotopes. Mineralium Deposita, 45, 419-441.

Maier, W. D., Barnes, S-J. and Ripley, E. M. (2011). The Kabanga Ni sulfide deposit, Tanzania: A review of ore-forming processes. Chapter 9 in: C. Li and E.M. Ripley (Editors), Magmatic Ni-Cu and PGE Deposits: Geology, Geochemistry, and Genesis, Society of Economic Geology Inc., Littleton, Colorado, U.S.A. pp 217234.

Mäkitie, H., Data, G., Isabirye, E., Mänttäri, I., Huhma, H., Klausen, M. B., Pakkanen, L. and Virransalo, P. (2014). Petrology, geochronology and emplacement model of the giant $1.37 \mathrm{Ga}$ arcuate Lake Victoria Dyke Swarm on the margin of a large igneous province in eastern Africa. Journal of African Earth
Sciences, 97, 273-297.

Marchand, J. (1996). L'économie minière en Afrique australe. Éditions Karthala, Paris, 424 pp.

Maske, S. and Cawthorn, R. G. (1986). The nickel occurrence in the Insizwa Complex, Transkei. In: C. R. Anhaeusser and S. Maske (Editors), Mineral Deposits of Southern Africa Volumes I and II, Geological Society of South Africa, Johannesburg, 2149-2158.

Mikesell, R. F. (1984). The Selebi-Phikwe nickel/copper mine in Botswana, lessons from a financial disaster. Natural Resources Forum, 8, 279-290.

Mudd, G. M. (2010). Global trends and environmental issues in nickel mining: Sulfides versus laterites. Ore Geology Reviews, 38, 926.

Mudd, G. M. and Jowitt, S. M. (2014). A detailed assessment of global nickel resource trends and endowments. Economic Geology, 109, 1813-1841.

Mwana Africa (2014). Operations and Exploration: Zimbabwe: Bindura Nickel Corp (BNC). Mwana Africa PLC corporate website, accessed on 09/02/2015 from: http://www.mwanaafrica. com/operations-and-exploration/zimbabwe/bindura-nickel-corpbnc.

Naldrett, A. J. (1999). World-class Ni-Cu-PGE deposits: key factors in their genesis. Mineralium Deposita, 34, 227-240.

Naldrett, A. J. (2004) Magmatic Sulfide Deposits: Geology, Geochemistry and Exploration. Heidelberg, Germany: SpringerVerlag, 728 pp.

Naldrett, A. J. (2010). Secular variation of magmatic sulphide deposits and their source magmas. Economic Geology, 105, 669-88.

Nile Basin Initiative (2014). Unlocking the Nile Basin's energy potential through cooperation. Case Study: Regional Rusumo Falls Hydroelectric Project. Downloaded on 27/01/2015 from http://www.rusumoproject.org/fileadmin/user_upload/ Documents/Rusumo_Project-Case_Study_July_2014.pdf.

Norilsk Nickel (2013). Norilsk Nickel Annual Report 2013. Downloaded from corporate website on 17/02/2015 from: http:/ /www.nornik.ru/assets/files/NN_AR_2013_en-fin-na-20iyunya.pdf

Programme des Nations Unies pour le Développement (1977). Recherches minières; Rapport technique: Les gisements latéritiques de nickel au Burundi. Report on findings of Project BDI/71-517; New York: Organisation des Nations Unies; 39 pp with 5 annexes.

Programme des Nations Unies pour le Développement (1979). Recherches minières; Rapport technique: Le gisement latéritique de nickel de Musongati, Plateau Buhinda et Rubara - deuxième campagne de recherche et évaluations. Final report project BDI/ 77-003; New York: Organisation des Nations Unies; pp, and annexes.

Ravenhurst, W. (2001). Step and impulse calculations from pulsetype electromagnetic data. Extended abstract presented at ASEG 15th Geophysical Conference and Exhibition, August 2001, Brisbane, Australia, 4 pp.

Salée, A. (1932). Carte géologique de l'Urundi méridional. Mémoire de l'Institut Géologique, Université de Louvain, $\mathrm{V}$ fasc 3.

Tack, L. and Deblond, A. (1990). Intrusive character of the Late Kibaran magmatism in Burundi. I.G.C.P. no. 255 Newsletter/ Bulletin, 3, 81-87.

Tack, L., Liègeois, J. P., Deblond, A. and Duchesne, J. C. (1994). Kibaran A-type granitoids and mafic rocks generated by two mantle sources in a late orogenic setting (Burundi). Precambrian Research, 68, 323-356.

Tack. L., Wingate, M.T.D., De Waele, B., Meert, J., Belousova, E., Griffin, B., Tahon, A. and Fernandez-Alonso, M. (2010). The $1375 \mathrm{Ma}$ "Kibaran event" in Central Africa: Prominent 
emplacement of bimodal magmatism under extensional regime. Precambrian Research, 180, 63-84.

Teale, E. O. (1932). Reconnaissance surveys along the east coast of Lake Tanganyika. Annual Report of the Geological Survey of Tanganyika, 1932, 22-24.

Tirschmann, P. A., MacDougall, C. S. and Katchen, G. R. (2010). Exploration, discovery, and geology of the Ntaka Hill nickel sulfide deposits: a potential new Proterozoic nickel district in the Nachingwea area, Mozambique Belt, Tanzania. Special Publication, Society of Economic Geologists, 15, 487-512.

United Nations Development Program (1980). United Nations Development Programme: Mineral Exploration in Northwest Tanzania, - Project Findings and Recommendations. Unpublished report by United Nations Development Program, New York, for Ministry of Energy and Mines, United Republic of Tanzania, $44 \mathrm{pp}$.

Van Zyl, C. (1959). An outline of the geology of the Kapalagulu Complex, Kungwe bay, Tanganyika Territory, and aspects of the evolution of layering in basic intrusive. Transactions of the

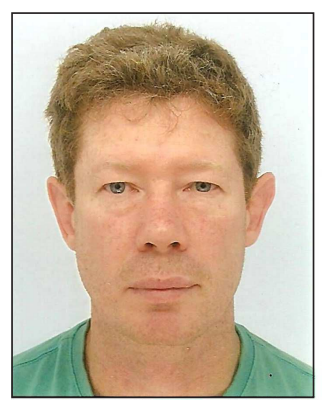

David Evans obtained $B S c$ and $P h D$ degrees at Imperial college (University of London). After completing post-doc research on the surface mobility of platinum-group elements from the Great Dyke, Zimbabwe, he joined BHP Minerals Exploration based in London and Cape Town. During his time with BHP he participated in the discovery of the highgrade nickel resource at Kabanga North and also consulted internally on nickel and platinum projects in Finland, Russia, Zimbabwe, South Africa and Namibia. Since 1999 he has been an independent consultant specialising in the management of projects, training of personnel and 3-D geological modelling for resource estimation.

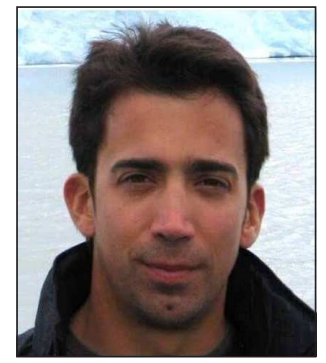

John Paul Hunt holds an MSc in Economic Geology from the Economic Geology Research Unit of the University of the Witwatersrand ( $U$ Wits) and postgraduate qualifications in Geostatistics and Resource Evaluation from $U$ Wits and UAlberta. He has spent much of his career studying and working on magmatic nickel sulphide mineralisation on 5 continents, including 3 years developing non-laterite nickel projects in Burundi for Norilsk Nickel Africa. He is currently a specialist scientist at the Council for Geoscience, involved in target generation and prospectivity modelling across all commodities and deposit types.
Geological Society of South Africa, 62, 1-31.

Wagner, P. A. (1929). The Platinum Deposits and Mines of South Africa. Edinburgh: Oliver and Boyd, 326 pp. \& 38 plates.

Waleffe, A. (1966). Etude géologique de l'est du Burundi et stratigraphie du Burundien. Department Geologie et Mineralogie, Rapport Annuel, 1965, Tervuren (Belgique): Musee Royale de l'Afrique Centrale, 69-74.

Westerhof, A. B. P., Härmä, P., Isabirye, E., Katto, E., Koistinen, T., Kuosmanen, E., Lehto, T., Lehtonen, M. I., Mäkitie, H., Manninen, T., Mänttäri, I., Pekkala, Y., Pokki, J., Saalmann, K. and Virransalo, P. (2014). Geology and Geodynamic Development of Uganda with Explanation of the 1:1,000,000 Scale Geological Map. Special Paper, Geological Survey of Finland, 55, 387 pp.

Wilhelmij, H. R. and Cabri, L. J. (2015). Platinum mineralization in the Kapalagulu Intrusion, western Tanzania. Mineralium Deposita, Online First; doi:10.1007/ s00126-015-0603-2.

Wolfgram, P. and Golden, H. (2001). Airborne EM applied to sulphide nickel: examples and analysis. Exploration Geophysics, 32, 136140.

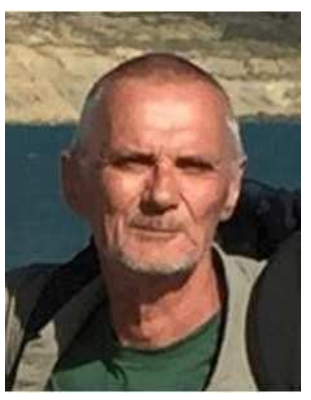

John Simmonds holds Honours and PhD degrees from the University of Wales, Cardiff and an MBA from the University of Western Australia. After 20 years with WMC Resources, he continued to focus on early-stage exploration for $\mathrm{Ni}-\mathrm{Cu}-\mathrm{PGE}$ mineral systems with several major and junior exploration companies in Africa and Asia. Since 2007, his role as Managing Director of Newgenco Group, has focused on greenfield discoveries in Canada, Scandinavia and West Africa. 